\title{
Faktor- Faktor Yang Mempengaruhi Kebijakan Dividen pada Sektor Trade, Service, And Investment Terdaftar Di Bursa Efek Indonesia Periode 2014-2018
}

\author{
Rut Br Ginting \\ Universitas Prima Indonesia \\ rutsyalomika28@gmail.com
}

Frisko Priwendamai

Universitas Prima Indonesia

friskopdsitompul@gmail.com

\author{
Candra Prima Samosir \\ Universitas Prima Indonesia \\ Chandrasamosir02@gmail.com
}

\author{
Wenny Anggeresia Ginting \\ Universitas Prima Indonesia \\ gintinganggresiawenny@gmail.com
}

\begin{abstract}
ABSTRAK
Penelitian ini bertujuan untuk menguji dan menganalisis bagaimana pengaruh Profitabilitas (Net Profit Margin), Ukuran Perusahaan (Firm Size), Leverage (Debt To Equity Ratio), dan Likuiditas (Cash Ratio) terhadap Kebijakan Dividen pada perusahaaan Trade, Service, and Investment yang terdaftar di Bursa Efek Indonesia periode 2014-2018. Metode penelitian yang digunakan dalam penelitian ini menggunakan metode pendekatan penelitian kuantitatif, jenis penelitian adalah deskriptif kuantitatif, sifat penelitian eksplanatory. Populasi penelitian ini sebanyak 132 perusahaan trade, service, and investment dengan teknik pengambilan sampel purpose sampling berjumlah 21 perusahaan trade, service, and investment yang memenuhi kriteria. Metode analisis data dalam penelitian ini adalah analisis regresi linear berganda dengan uji asumsi klasik. Hasil penelitian ini menunjukkan secara simultan Profitabilitas (Net Profit Margin), Ukuran Perusahaan (Firm Size), Leverage (Debt To Equity Ratio), dan Likuiditas (Cash Ratio)berpengaruh dan signifikan terhadap Kebijakan Dividen pada perusahaan sektor trade, service, and investment yang terdaftar di Bursa Efek Indonesia periode 2014-2018 dengan hasil $F_{\text {hitung }} \geq F_{\text {tabel }} 2,899 \geq$ 2,46 dan signifikan 0,026 $\leq \mathbf{0 , 0 5}$. Secara parsial Ukuran Perusahaanberpengaruh dan tidak signifikan terhadap Kebijakan Dividen, sedangkan Net Profit Margin, Debt To Equity Ratio, dan Cash Ratiotidak berpengaruh dan tidak signifikan terhadap Kebijakan Dividen. Hasil analisis koefisien determinasi diperoleh nilai Adjusted R2 menunjukkan variasi variabel Kebijakan Dividen yang dapat dijelaskan oleh variasi variabel Profitabilitas (Net Profit Margin), Ukuran Perusahaan (Firm Size), Leverage (Debt To Equity Ratio), dan Likuiditas (Cash Ratio) sebesar 3,1\% sedangkan sisanya sebesar 96,9\% dijelaskan oleh variasi variabel lainnya.
\end{abstract}

Kata Kunci : Profitabilitas, Ukuran Perusahaan, Leverage, Likuiditas, Kebijakan Dividen

\section{PENDAHULUAN}

Dari berbagai sektor industri yang terdaftar di BEI, sektor yang menjadi objek penelitian ini adalah sektor trade, service, and investment. Di Indonesia, perkembangan perusahaan perdagangan ritel cukup pesat, serta lebih menjanjikan dilihat bahwa masyarakat Indonesia merupakan masyarakat konsumtif. Alasan peneliti memilih trade, service, and investment ialah dari sisi volume perdagangan, neraca perdagangan Indonesia mengalami surplus 34,03 juta ton pada Desember 2017. Namun, neraca volume perdagangan sektor migas defisit 0,87 juta ton. Meski pada Desember terjadi defisit, namun secara keseluruhan neraca perdagangan Indonesia pada 2017 mengalami surplus sebesar USD 11,84 miliar dibandingkan dengan total surplus pada 2016 sebesar USD 9,53 miliar. Neraca perdagangan Indonesia surplus terhadap tiga negara, yakni India, Amerika Serikat dan Belanda, sedangkan defisit terjadi pada Tiongkok, Thailand dan Australia.

Seorang investor dalam menginvestasikan dananya di pasar modal bertujuan untuk bisa 
memperoleh dividen. Kebijakan dividen merupakan keputusan setelah perusahaan beroperasi dan memperoleh laba.

Keputusan untuk memberikan dividen kepada pemegang saham melibatkan dua pihak yang berbeda kepentingan, yaitu antara perusahaan dan investor. Oleh karena itu, untuk mengukur kebijakan dividen indikator yang digunakan, yaitu Dividend Payout Ratio (DPR) yang merupakan keputusan untuk menentukan seberapa banyak dividen yang akan dibagikan kepada pemegang saham.

Laba Bersih Setelah Pajak menjadi salah satu perhatian investor karena akan menjadi tolak ukur bagaimana perusahaan tersebut mampu bertahan dalam bisnisnya. Semakin tinggi tingkat laba (profit) yang didapat sebuah perusahaan maka kemungkinan pembagian dividen akan semakin besar. Penelitian ini akan menggunakan NPM, yaitu laba bersih dibagi dengan penjualan sebagai alat ukur karena sangat berkaitan dengan saham yang dimiliki investor.

Ukuran perusahaan menjelaskan tentang keadaan atau kondisi yang terjadi pada suatu perusahaan. Jika suatu perusahaan yang besar dan mapan akan memiliki akses yang lebih mudah ke pasar modal, maka sebaliknya perusahaan kecil akan lebih sulit mengakses ke pasar modal. Apabila suatu perusahaan telah mencapai tingkat pertumbuhan sedemikian, dimana kebutuhan atas dana dapat terpenuhi dengan dana yang berasal dari pasar modal atau sumber dana eksteren lainnya, maka perusahaan berkesempatan untuk membayar dividen kepada para pemegang saham.

Total hutang karena jika dalam sebuah perusahaan total hutang yang terlalu tinggi akan memberikan dampak yang kurang baik terhadap perusahaan karena perusahaan tersebut harus membayar kewajiban-kewajibannya. Utang perusahaan tinggi maka investor tidak akan tertarik untuk membeli saham perusahaan karena tidak sesuai dengan harapan investor yaitu bagian dividen. Yang artinya semakin tinggi total hutang maka akan semakin kecil dividen yang akan dibagikan kepada para pemegang saham karena kewajiban untuk membayar hutang lebih diutamakan dari pada pembagian dividen.

Kas karena disini dapat dilihat bagaimana posisi kas dalam sebuah perusahaan dimana faktor penting yang harus dipertimbangkan sebelum sebuah perusahaan membuat keputusan dalam menentukan seberapa besar dividen yanga akan dibayarkan kepada para pemegang saham. Penelitian ini menggunakan cash ratio yaitu kas dibandingkan dengan utang lancar sebagai alat ukur karena kas merupakan aktiva lancar yang paling likuid.Semakin likuid sebuah perusahaan, kemungkinan pembayaran dividen yang dilakukan perusahaan tersebut akan semakin besar.

\section{TINJAUAN PUSTAKA}

Menurut (sutrisno, 2013) bagi perusahaan yang pendapatannya stabil, dividen yang dibayarkan kepada pemegang saham lebih besar dibanding dengan perusahaan yang pendapatannya tidak stabil.Menurut (Mulyawan, 2015) perusahaan yang mempunyailaba stabil akan mampu memperkirakan besarnya laba pada masa yang akan datang. Perusahaan ini cenderung membayarkan dividend payout ratio, daripada perusahaan yang labanya berfluktuasi, dividen yang lebih rendah akan lebih mudah untuk dibayar apabila laba menurun pada masa yang akan datang.

Menurut (Gumanti, 2013) ada kecenderungan yang nyata dan berpola antara ukuran perusahaan dan besar kecilnya rasio pembayaran dividen. Perusahaan yang secara ekonomi dikelompokkan sebagai perusahaan besar, biasanya diukur dengan tingkat kapitalisasi pasar sahamnya, secara rata-rata memiliki rasio pembayaran dividen lebih tinggi daripada perusahaan kecil.

Menurut (Rodoni \& Ali, 2014) perusahaan perusahaan yang sedang tumbuh akan memberikan dividen relatif rendah pada awalnya. Hal ini dikarenakan adanya rencana reinvestasi dari sebagian laba yang diperoleh untuk membiayai aktivitas ekpansi. Tetapi perusahaan-perusahaan yang termasuk kelompok perusahaan yang sedang tumbuh akan menghasilkan tingkat pertumbuhan dividen yang lebih tinggi pada tahun-tahun berikutnya.

Menurut (Riyanto, 2010) Apabila perusahaan menetapkan bahwa pelunasan utangnya akan diambilkan dari laba ditahan, berarti perusahaan harus menahan sebagian besar dari pendapatannya untuk keperluan tersebut, yang ini berarti bahwa hanya sebagian kecil saja dari pendapatan atau earning yang dapat dibayarkan sebagai dividen. Dengan kata lain perusahaan harus menetapkan dividend payout ratio yang rendah.

Menurut (Gumanti, 2013) Jika perusahaan memiliki kewajiban (utang) yang besar dan harus segerah dibayar, maka sangat mungkin bahwa pemegang saham harus dikorbankan, yaitu menunda atau mengurangi pembayaran dividen.

Menurut (sutrisno, 2013) bagi perusahaan yang kondisi likuiditasnya kurang baik, biasanya dividend payout rationya kecil, sebab sebagian besar laba digunakan untuk menambah likuiditas.Menurut (Mulyawan, 2015) karena dividen merupakan arus kas keluar, semakin besar jumlah kas yang tersedia 
dari likuiditas perusahaan, semakin besar pula kemampuan perusahaan untuk membayar dividen.

Menurut (Hery, 2015) dividen merupakan suatu kegiatan yang bersifat cash outflow, sehingga semakin tinggi tingkat likuiditas perusahaan maka akan semakin mampu perusahaan dalam membayar dividen.

(Agustina \& Andayani) dalam Jurnal Ilmu dan Riset Akuntansi menunjukkan bahwa makin besarjumlah aktiva lancar yang dimiliki oleh suatu perusahaandibandingkan dengan hutanglancar, maka makin besar tingkat likuiditas perusahaan tersebut sertapembayaran dividenbagi para investor yang menanamkan modalnya pada perusahaan tersebut.

\section{METODOLOGI PENELITIAN}

\section{a. Jenis Penelitian}

Penelitian ini menggunakan metode penelitian kuantitatif. Data kuantitatif yang digunakan dalam penelitian ini adalah data sekunder yaitu laporan keuangan yang dipublikasikan oleh Bursa Efek Indonesia. Sumber data didapatkan dengan studi dokumentasi. Jenis penelitian yang digunakan adalah statistik deskriptif dan sifat penelitian ini adalah hubungan explanatory.

Populasi penelitian ini adalah 132 perusahaan dari sektor Trade, Service, and Invesrment yang terdaftar di Bursa Efek Indonesia periode 2014-2018 bersumber dari www.idx.co.id

Sampel penelitian ini adalah laporan keuangan Perusahaan Sektor Trade, Service, and Investment periode 2014-2018.

Dalam penelitian ini, kriteria yang ditetapkan adalah sebagai berikut: Perusahaan Sektor Trade, Service, and Investment yang terdaftar di BEI periode 2014-2018.

1. Perusahaan Sektor Trade, Service, and Investment yang mempublish laporan keuangan lengkap periode 2014-2018.

2. Perusahaaan Sektor Trade, Service, and Investment yang mempublish laporan keuangan dalam satuan Rupiah periode 2014-2018.

3. Perusahaaan Sektor Trade, Service, and Investment yang memiliki laba periode 20142018.

4. Perusahaaan Sektor Trade, Service, and Investment yang membagikan Dividen periode 2014-2018.

\begin{tabular}{|l|l|l|}
\hline No & Kriteria & Jumlah \\
\hline
\end{tabular}

\begin{tabular}{|c|l|c|}
\hline 1 & $\begin{array}{l}\text { Perusahaan Sektor Trade, Service, and } \\
\text { Investmentyang terdaftar di BEI } \\
\text { periode 2014-2018. }\end{array}$ & 132 \\
\hline 2 & $\begin{array}{l}\text { Perusahaaan Sektor Trade, Service, } \\
\text { and Investment yang tidak } \\
\text { mempublish laporan keuangan } \\
\text { lengkap periode 2014-2018. }\end{array}$ & $(31)$ \\
\hline 3 & $\begin{array}{l}\text { Perusahaaan Sektor Trade, Service, } \\
\text { and Investment yang tidak } \\
\text { mempublish laporan keuangan dalam } \\
\text { satuan Rupiah periode 2014-2018. }\end{array}$ & $(10)$ \\
\hline 4 & $\begin{array}{l}\text { Perusahaaan Sektor Trade, Service, } \\
\text { and Investment yang mengalami } \\
\text { kerugian periode 2014-2018. }\end{array}$ & $(21)$ \\
\hline 5 & $\begin{array}{l}\text { Perusahaaan Sektor Trade, Service, } \\
\text { and Investment yang tidak } \\
\text { membagikan Dividen periode 2014- } \\
\text { 2018. }\end{array}$ & (49) \\
\hline $\begin{array}{l}\text { Jumlah perusahaan yang terpilih menjadi } \\
\text { sampel penelitian }\end{array}$ & $\mathbf{2 1}$ \\
\hline
\end{tabular}

Sumber data : data sekunder diolah

Berdasarkan kriteria-kriteria tersebut, maka sampel yang digunakan dalam penelitian ini adalah sebanyak 21 sampel, sehingga observasi pengamatan menjadi $21 \times 5=105$

b. Analisis Regresi Berganda

Untuk mengetahui pengaruh variabel bebas dan variabel terikat digunakan rumus analisis linear berganda sebagai berikut :

$$
\mathrm{Y}=\mathrm{a}+\mathrm{b}_{1} \mathrm{X}_{1}+\mathrm{b}_{2} \mathrm{X}_{2}+\mathrm{b}_{3} \mathrm{X}_{3}+\mathrm{b}_{4} \mathrm{X}_{4}+\mathrm{e}
$$

Untuk penelitian ini dapat diperoleh keterangan sebagai berikut :

$$
\begin{array}{ll}
\mathrm{Y} & =\text { Dividend Payout Ratio (DPR) } \\
\mathrm{a} & =\text { Bilangan Konstanta } \\
\mathrm{b}_{1} \mathrm{~b}_{2} \mathrm{~b}_{3} & =\text { Koefisien Regresi } \\
\mathrm{X}_{1} & =\text { Net Profit Margin (NPM) } \\
\mathrm{X}_{2} & =\text { Ukuran Perusahaan (Firm Size) } \\
\mathrm{X}_{3} & =\text { Leverage (DER) } \\
\mathrm{X}_{4} & =\text { Likuiditas (Cash Ratio) } \\
\mathrm{e} & =\text { Standar Error }(5 \%)
\end{array}
$$

bersama-sama atau simultan terhadap variabel dependen. Apabila nilai $F_{\text {hitung }}$ lebih besar

\section{HASIL DAN PEMBAHASAN}

a. Statistik Deskriptif

Statistik deskriptif memberikan gambaran mengenai nilai minimum, nilai maksimum, nilai ratarata, dan standar deviasi untuk data yang digunakan dalam penelitian. Statistik deskriptif pada penelitian ini dapat dilihat pada tabel berikut.

\section{Tabel 2. Statistik Deskriptif}




\begin{tabular}{|l|r|r|r|r|r|}
\hline \multicolumn{7}{|c|}{ Descriptive Statistics } \\
\hline & N & Minimum & Maximum & Mean & $\begin{array}{c}\text { Std. } \\
\text { Deviation }\end{array}$ \\
\hline NPM & 105 &, 0060 &, 3598 &, 099843 &, 0888371 \\
\hline FS & 105 & 24,8992 & 30,9972 & 28,559812 & 1,3066870 \\
\hline DER & 105 &, 0359 & 18,1924 & 1,182681 & 1,8969045 \\
\hline CR & 105 &, 0020 & 5,2997 &, 656339 &, 7616891 \\
\hline DPR & 105 &, 0106 & 2,0754 &, 351156 &, 3086724 \\
\hline $\begin{array}{l}\text { Valid N } \\
\text { (listwise) }\end{array}$ & 105 & & & & \\
\hline
\end{tabular}

\section{Sumber : Olahan Data SPSS 22}

\section{b. Hasil Uji Asumsi Klasik}

Uji normalitas bertujuan untuk menguji apakah model regresi residual memiliki distribusi normal. Ada dua cara untuk mendeteksi apakah residual berdistribusi normal atau tidak normal dengan melihat analisi grafik histogram dan uji statistik Kolmogorov Smirnov.

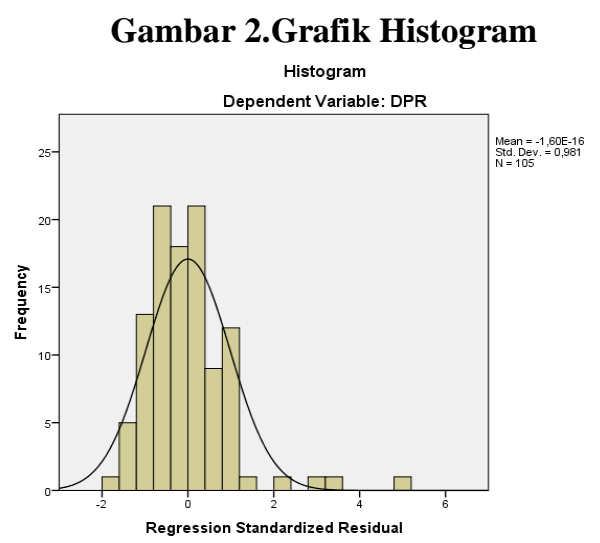

Sumber : Olahan data SPSS 22

Dari grafik histogram pada Gambar 2. diatas terlihat bahwa grafik histogram memperlihatkan pola distribusi normal dimana garis kurva cenderung simetri (U).

\section{Gambar 3.Grafik Normality P-Plot}

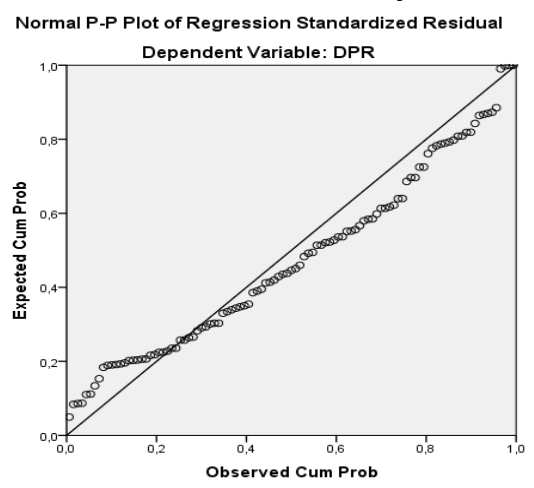

Sumber : Olahan Data SPSS 22
Berdasarkan hasil uji normalitas P-Plot pada gambar diatas pola titik-titik mengikuti garis diagonal. Dengan demikian hasil ini dapat disimpulkan data berdistribusi normal.

Tabel 3.Hasil Uji Kolmogorov Smirnov One-Sample Kolmogorov-Smirnov Test

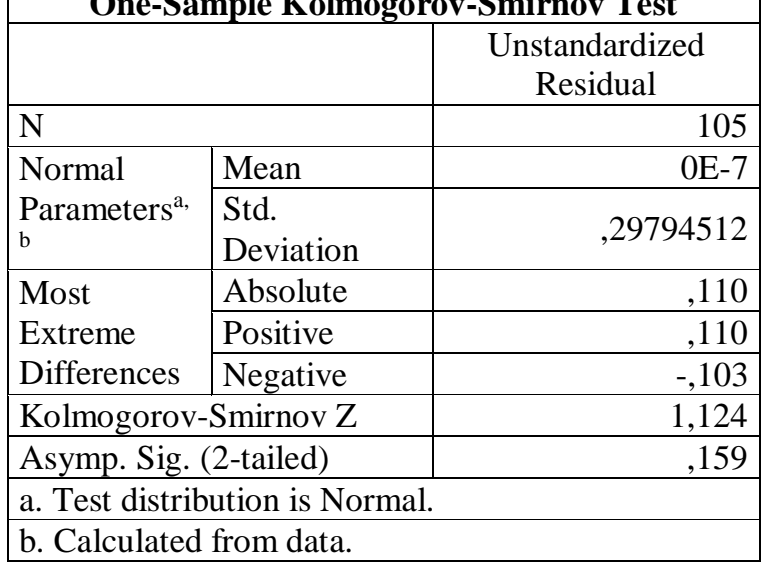

\section{Sumber : Olahan Data SPSS 22}

Dari tabel diatas dapat dilihat bahwa data dalam model regresi telah berdistribusi normal karena variabel mempunyai nilai signifikan yang lebih besar dari 0,05 yaitu 0,159 .

c. Uji Multikolonieritas

Uji multikolonieritas digunakan untuk menguji apakah dalam model regresi ditemukan adanya korelasi antar variabel independen. Model regresi yang baik seharusnya tidak terjadi korelasi diantara variabel independen.Pengambilan keputusan yaitu nilai VIF $\leq 10$ dan nilai Tolerance $\geq 0,10$ maka regresi bebas dari multikolonieritas.

\section{d. Uji Autokorelasi}

Uji Autokorelasi digunakan untuk menguji apakah dalam sebuah model regresi linier ada korelasi antara kesalahan pengganggu pada periode $t$ dengan kesalahan pengganggu pada periode $\mathrm{t}-1$ (periode sebelumnya). Salah satu ukuran dalam menentukan ada tidaknya masalah Autokorelasi dengan Uji Durbin-Watson (DW).

Tabel 4.Hasil Uji Multikolonieritas

\begin{tabular}{|c|c|c|c|c|c|c|c|c|}
\hline \multicolumn{9}{|c|}{ Coefficients $^{\mathrm{a}}$} \\
\hline \multirow{2}{*}{\multicolumn{2}{|c|}{ Model }} & \multicolumn{2}{|c|}{$\begin{array}{c}\text { Unstandardized } \\
\text { Coefficients }\end{array}$} & \multirow{2}{*}{$\begin{array}{c}\begin{array}{r}\text { Standardized } \\
\text { Coefficients }\end{array} \\
\text { Beta }\end{array}$} & \multirow[t]{2}{*}{$\mathrm{t}$} & \multirow[t]{2}{*}{ Sig. } & \multicolumn{2}{|c|}{$\begin{array}{c}\text { Collinearity } \\
\text { Statistics }\end{array}$} \\
\hline & & B & $\begin{array}{c}\text { Std. } \\
\text { Error }\end{array}$ & & & & Tolerance & VIF \\
\hline \multirow{5}{*}{1} & (Constant) & ,973 & ,705 & & 1,379 & ,171 & & \\
\hline & NPM &, 527 &, 360 &, 152 & 1,466 & ,146 & ,869 & 1,151 \\
\hline & FS &,- 024 &, 025 &,- 103 &,- 992 & ,323 & 864 & 1,157 \\
\hline & DER &,- 008 &, 016 &,- 049 &,- 496 & ,621 & ,947 & 1,056 \\
\hline & CR & ,046 & , 044 &, 115 & 1,043 & 299 & ,773 & 1,294 \\
\hline
\end{tabular}

Sumber : Olahan Data SPSS 22 
Dari tabel tersebut, Nilai tolerance semua variabel independen $>0,10$, yaitu NPM $\left(\mathrm{X}_{1}\right)=0,869$; Firm Size $\left(\mathrm{X}_{2}\right)=0,864$; DER $\left(\mathrm{X}_{3}\right)=0,947$, dan CR $\left(X_{4}\right)=0,735$. Sedangkan, VIF $<10$, yaitu NPM $\left(X_{1}\right)$ $=1,151 ;$ Firm Size $\left(\mathrm{X}_{2}\right)=1,57$; DER $\left(\mathrm{X}_{3}\right)=1,056$, dan $\mathrm{CR}\left(\mathrm{X}_{4}\right)=1,294$. Sehingga, dapat disimpulkan bahwa pada model regresi tidak terjadi multikolonieritas.

Tabel 5.Hasil Uji Autokorelasi

\begin{tabular}{|l|c|c|c|r|c|}
\hline \multicolumn{7}{|c|}{ Model Summary $^{\mathbf{b}}$} \\
\hline $\begin{array}{l}\text { Mode } \\
1\end{array}$ & $\mathrm{R}$ & $\begin{array}{c}\mathrm{R} \\
\text { Squar } \\
\mathrm{e}\end{array}$ & $\begin{array}{c}\text { Adjuste } \\
\mathrm{d} \mathrm{R} \\
\text { Square }\end{array}$ & $\begin{array}{c}\text { Std. } \\
\text { Error of } \\
\text { the } \\
\text { Estimate }\end{array}$ & $\begin{array}{c}\text { Durbin } \\
- \\
\text { Watso } \\
\mathrm{n}\end{array}$ \\
\hline 1 & $\begin{array}{r}261 \\
\mathrm{a}\end{array}$ &, 068 &, 031 & $\begin{array}{r}, 303845 \\
6\end{array}$ & 2,071 \\
\hline
\end{tabular}

a. Predictors: (Constant), CR, DER, NPM, FS b. Dependent Variable: DPR

\section{Sumber : Olahan Data SPSS 22}

Berdasarkan Tabel 5. Hasil Uji Durbin Watson menunjukan bahwa nilai Durbin Watson 2,512, sedangkan dalam tabel DW "K"=4. pengujian $\mathrm{du}<\mathrm{d}<4-\mathrm{dl}$. Nilai dl dan du dalam penelitian ini dengan jumlah 5 variabel dan 105 sampel adalah nilai $\mathrm{dl}=1,6038$ dan nilai $\mathrm{du}=1,7617$. Maka hasil pengukurannya adalah $1,7617<2,071<(4-1,6038)$, yaitu $1,7617<2,071<2,3962$. Sehingga dapat di simpulkan bahwa tidak ada autokorelasi dalam model regresi penelitian ini.

\section{e. Uji Heteroskedastisitas}

Uji Heteroskedastisitas berguna untuk menguji apakah model regresi terjadi ketidaksamaan variance dari residual satu pengamatan ke pengamatan yang lain. Model regresi yang baik adalah tidak terjadi heteroskedastisitas.Pengujian dilakukan dengan menggunakan Grafik Scatterplot dan Uji Glejser.

\section{Gambar 4.Hasil Pengujian Scatterplot} Scatterplot

Dependent Variable: DPR

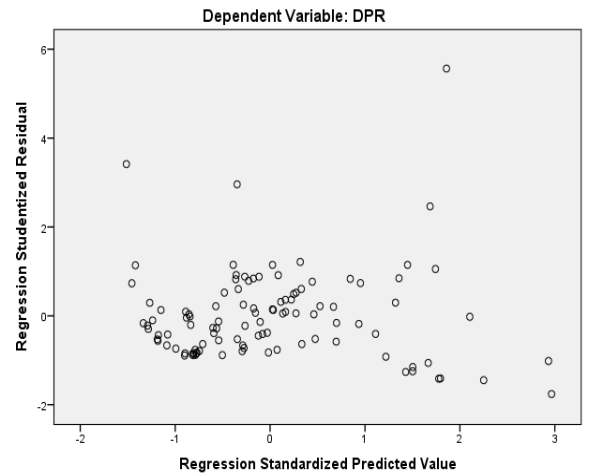

Sumber : Olahan Data SPSS
Berdasarkan Gambar 4. Hasil pengujian Scatterplot diatas terlihat bahwa titik-titk (plot) menyebar secara acak, baik diatas maupun di bawah angka nol (0) pada sumbu Y, tidak berkumpul di satu tempat. Oleh karena itu, berdasarkan uji Heteroskedastisitas dengan metode analisis grafik dinyatakan tidak terjadi gejala Heteroskedastisitas.

\section{Tabel 6.Hasil Uji Glejser}

\begin{tabular}{|c|c|c|c|c|c|c|c|c|}
\hline \multicolumn{9}{|c|}{ Coefficients $^{\mathbf{a}}$} \\
\hline \multirow{2}{*}{\multicolumn{2}{|c|}{ Model }} & \multicolumn{2}{|c|}{$\begin{array}{c}\text { Unstandardized } \\
\text { Coefficients }\end{array}$} & \multirow{2}{*}{$\begin{array}{c}\text { Standardized } \\
\text { Coefficients } \\
\text { Beta }\end{array}$} & \multirow[t]{2}{*}{$\mathrm{t}$} & \multirow[t]{2}{*}{ Sig. } & \multicolumn{2}{|c|}{$\begin{array}{c}\text { Collinearity } \\
\text { Statistics }\end{array}$} \\
\hline & & B & $\begin{array}{c}\text { Std. } \\
\text { Error }\end{array}$ & & & & Tolerance & $\begin{array}{l}\text { VI } \\
\text { F }\end{array}$ \\
\hline \multirow{5}{*}{1} & (Constant) & ,973 & ,705 & & 1,379 & ,171 & & \\
\hline & NPM & ,527 & ,360 & , 152 & 1,466 & , 146 & ,869 & $\begin{array}{r}1,1 \\
51\end{array}$ \\
\hline & FS &,- 024 & ,025 &,- 103 &,- 992 & ,323 & ,864 & $\begin{array}{l}1,1 \\
57\end{array}$ \\
\hline & DER &,- 008 & ,016 &,- 049 &,- 496 & 621 & ,947 & $\begin{array}{r}1,0 \\
56\end{array}$ \\
\hline & CR & ,046 & ,044 & ,115 & 1,043 & ,299 & ,773 & $\begin{array}{r}1,2 \\
94\end{array}$ \\
\hline
\end{tabular}

\section{Sumber : Olahan Data SPSS}

Hasil Uji Glejser pada Tabel 6. setelah transformasi menunjukkan nilai signifikan dari 4 variabel independen lebih besar dari 0,05. Dengan demikian dari hasil Uji Glejser dapat disimpulkan tidak terjadi masalah heteroskedastisitas.

\section{f. Hasil Analisis Data Penelitian}

Pengujian hipotesis yang digunakan dalam penelitian ini adalah dengan menggunakan analisi regresi linier berganda. Model regresi yang digunakan adalah sebagai berikut:

Tabel 7.Hasil Uji Model Regresi Linier Berganda

\begin{tabular}{|c|c|c|c|c|c|c|c|c|}
\hline \multicolumn{9}{|c|}{ Coefficients $^{\mathrm{a}}$} \\
\hline \multirow{2}{*}{\multicolumn{2}{|c|}{ Model }} & \multicolumn{2}{|c|}{$\begin{array}{c}\text { Unstandardized } \\
\text { Coefficients }\end{array}$} & \multirow{2}{*}{$\begin{array}{c}\begin{array}{c}\text { Standardized } \\
\text { Coefficients }\end{array} \\
\text { Beta }\end{array}$} & \multirow[t]{2}{*}{$\mathrm{t}$} & \multirow[t]{2}{*}{ Sig. } & \multicolumn{2}{|c|}{$\begin{array}{c}\text { Collinearity } \\
\text { Statistics }\end{array}$} \\
\hline & & B & $\begin{array}{l}\text { Std. } \\
\text { Error }\end{array}$ & & & & Tolerance & VIF \\
\hline \multirow{5}{*}{1} & (Constant) & ,973 & ,705 & & 1,379 & ,171 & & \\
\hline & NPM & ,527 & ,360 &, 152 & 1,466 & , 146 & ,869 & 1,151 \\
\hline & FS &,- 024 & 025 &,- 103 &,- 992 & ,323 & ,864 & 1,157 \\
\hline & DER &,- 008 & ,016 &,- 049 &,- 496 &, 621 & ,947 & 1,056 \\
\hline & $\mathrm{CR}$ & ,046 & ,044 &, 115 & 1,043 & 299 & ,773 & 1,294 \\
\hline
\end{tabular}

\section{Sumber: Olahan Data SPSS}

Berdasarkan Tabel 7. diatas maka dapat diperoleh persamaan regresi Linier Berganda sebagai berikut:

$$
\mathrm{Y}=\mathrm{a}+\mathrm{b} 1 \mathrm{X} 1+\mathrm{b} 2 \mathrm{X} 2-\mathrm{b} 3 \mathrm{X} 3+\mathrm{b} 4 \mathrm{X} 4+\mathrm{e}
$$

Kebijakan Dividen $=0,973+0,527$ (Net Profit Margin) - 0,024 (Firm Size)-0,008(Debt To Equity Ratio $)+0,046$ (Cash Ratio) berikut :

Hasil Interpretasi dari regresi tersebut sebagai

1. Nilai konstanta (a) sebesar 0,973, artinya jika nilai variabel Net Profit Margin (X1),Firm Size (X2), Debt To Equity Ratio (X3), dan Cash 
Ratio (X4) dianggap konstan maka Kebijakan Dividen adalah 0,973.

2. Nilai koefisien Net Profit Margin (X1) sebesar 0,527 hal ini menunjukan bahwasetiap kenaikan Net Profit Margin (X1) satu satuan maka Kebijakan Dividen mengalami kenaikan sebesar 0,527 satuan.

3. Nilai koefisien Firm Size (X2) sebesar 0,024 hal ini menunjukan bahwa setiap kenaikan Firm Size (FS) satu satuan maka Kebijakan Dividen akan mengalami penurunan sebesar 0,024 satuan.

4. Nilai Koefisien Debt To Equity Ratio (X3) sebesar 0,008 hal ini menunjukan bahwa setiap kenaikan Debt To Equity Ratio (DER) satu satuan maka Kebijakan Dividen akan mengalami penurunan sebesar 0,008 satuan.

5. Nilai Koefisien Cash Ratio (X4) sebesar 0,046 hal ini menunjukan bahwa setiap kenaikan Cash Ratio(CR) satu satuan maka Kebijakan Dividen akan mengalami kenaikan sebesar 0,046 satuan.

g. Koefisien Determinasi $\left(\mathrm{R}^{2}\right)$

Koefisien determinasi digunakan untuk mengukur seberapa besar kemampuan pengaruh variabel bebas dapat menjelaskan variabel terikat. Koefisien determinasi $\left(\mathrm{R}^{2}\right)$ semakin besar maka semakin baik kemampuan variabel bebas (X) menerangkan variabel terikat $(\mathrm{Y})$ berikut ini nilai koefisien determinasi:

Tabel 8.Hasil Uji Koefisien Determinasi $\left(\mathbf{R}^{2}\right)$

\begin{tabular}{|l|c|r|c|c|c|}
\hline \multicolumn{5}{|c|}{ Model Summary $^{\mathbf{b}}$} \\
\hline Model & $\mathrm{R}$ & $\begin{array}{c}\mathrm{R} \\
\text { Square }\end{array}$ & $\begin{array}{c}\text { Adjusted R } \\
\text { Square }\end{array}$ & $\begin{array}{c}\text { Std. Error of the } \\
\text { Estimate }\end{array}$ & $\begin{array}{c}\text { Durbin- } \\
\text { Watson }\end{array}$ \\
\hline 1 &, $261^{\mathrm{a}}$ &, 068 &, 031 &, 3038456 & 2,071 \\
\hline \multicolumn{6}{|l}{ a. Predictors: (Constant), CR, DER, NPM, FS } \\
\hline
\end{tabular}

b. Dependent Variable: DPR

\section{Sumber : Olahan Data SPSS}

Berdasarkan Tabel 8. diatas menunjukan bahwa nilai Adjusted $\mathrm{R}^{2}$ yang diperoleh adalah 0,031 atau sama dengan 3,1\% variabel independen (Kebijakan Dividen) dapat dijelaskan oleh variasi dari variabel bebas (Net Profit Margin, Firm Size, Debt To Equity Ratio, dan Cash Ratio). Sedangkan sisanya sebesar 96,9\% dipengaruhi oleh variabel lainnya.

h. Pengujian Hipotesis Secara Simultan (F)

Uji $F$ digunakan untuk menguji apakah variabel independen secara bersama- sama mempengaruhi variabel dependen. Berdasarkan hasil pengolahan data maka diperoleh hasil Uji F sebagai berikut :
Tabel 9. Uji F ANOVA

\begin{tabular}{|l|l|r|r|r|r|r|}
\hline Model & $\begin{array}{r}\text { Sum of } \\
\text { Square } \\
\text { s }\end{array}$ & Df & $\begin{array}{r}\text { Mean } \\
\text { Squar } \\
\text { e }\end{array}$ & F & Sig. \\
\hline \multirow{2}{*}{1} & $\begin{array}{l}\text { Regressio } \\
\text { n }\end{array}$ &, 485 & 4 &, 121 & $\begin{array}{r}2,89 \\
9\end{array}$ & $\begin{array}{r}, 026 \\
\text { b }\end{array}$ \\
\cline { 2 - 7 } & Residual & 4,185 & $\begin{array}{r}10 \\
0\end{array}$ &, 042 & & \\
\cline { 2 - 6 } & Total & 4,670 & $\begin{array}{r}10 \\
4\end{array}$ & & & \\
\hline
\end{tabular}

\section{Sumber : Olahan Data SPSS}

Dari Tabel 9. di atas dapat diketahui bahwa secara simultan atau bersama sama (Uji F) variabel independen berpengaruh dan signifkan terhadap variabel dependen. Hal ini dapat dibuktikan dari nilai

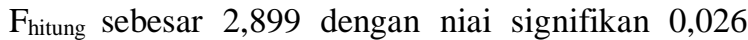
sedangkan $F_{\text {tabel }}$ sebesar 2,46 dengan signifikan 0,05. Dengan demikian dapat dilihat bahwa $\mathrm{F}_{\text {hitung }} \geq \mathrm{F}_{\text {tabel }}$ atau signifikan $2,899 \geq 2,46$ dan $0,026 \leq 0,05$. Sehingga $\mathrm{H}_{\mathrm{a}}$ di terima dimanaNet Profit Margin, Firm Size, Debt To Equity Ratio, dan Cash Ratio secara simultan berpengaruh signifikan terhadap Kebijakan Dividen pada perusahaan sektorTrade, Service, and Investment yang terdaftar di Bursa Efek Indonesia periode 2014-2018.

i. Pengujian Hipotesis Secara Parsial (t)

Uji $\mathrm{t}$ dilakukan untuk mengetahui pengaruh masing- masing atau secara parsial variabel independen mempengaruhi variabel dependen. Berdasarkan hasil pengolahan data maka diperoleh hasil Uji t sebagai berikut :

Tabel 10.Hasil Uji t

\begin{tabular}{|c|c|c|c|c|c|c|c|c|}
\hline \multicolumn{9}{|c|}{ Coefficients $^{\mathrm{a}}$} \\
\hline \multirow{2}{*}{\multicolumn{2}{|c|}{ Model }} & \multicolumn{2}{|c|}{$\begin{array}{c}\text { Unstandardized } \\
\text { Coefficients }\end{array}$} & \multirow{2}{*}{\begin{tabular}{|c|}
$\begin{array}{r}\text { Standardized } \\
\text { Coefficients }\end{array}$ \\
Beta
\end{tabular}} & \multirow[t]{2}{*}{$\mathrm{t}$} & \multirow[t]{2}{*}{ Sig. } & \multicolumn{2}{|c|}{$\begin{array}{c}\text { Collinearity } \\
\text { Statistics }\end{array}$} \\
\hline & & B & $\begin{array}{l}\text { Std. } \\
\text { Error }\end{array}$ & & & & Tolerance & VIF \\
\hline \multirow{5}{*}{1} & (Constant) & 1,077 &, 475 & & 2,268 &, 025 & & \\
\hline & \begin{tabular}{|l|} 
NPM \\
\end{tabular} &, 138 &, 242 &, 058 &, 571 &, 569 & ,869 & 1,151 \\
\hline & FS &,- 032 & ,017 &,- 195 & 1,916 &, 058 & ,864 & 1,157 \\
\hline & DER &,- 007 & ,011 &,- 066 &,- 679 & ,499 & ,947 & 1,056 \\
\hline & CR & ,046 & ,030 & , 166 & 1,545 & ,126 & ,773 & 1,294 \\
\hline
\end{tabular}

\section{Sumber : Olahan Data SPSS}

Berdasarkan Tabel 10., maka pengaruh masing-masing variabel Net Profit Margin, Firm Size, Debt To Equity Ratio, dan Cash Ratio secara parsial terhadap Nilai Perusahaan dapat dilihat dari arah tanda dan tingkat signifikan (Probabilitas). Hasil pengujian hipotesis masing-masing variabel independen secara parsial terhadap variabel dependen dapat dianalisis sebagai berikut :

1. Variabel Return On Equity $\left(\mathrm{X}_{1}\right)$ mempunyai nilai $t_{\text {hitung }}$ 0,571 dengan tingkat signifikan 0,569. Sedangkan nilai $t_{\text {tabel }}$ adalah sebesar 
1,66023dengan signifikan 0,05. Sehingga kesimpulannya adalah $t_{\text {hitung }}<t_{\text {tabelyaitu }} 0,571>$ 1,66023. Maka keputusannya adalah $\mathrm{H}_{\mathrm{o}}$ diterima dan $\mathrm{H}_{\mathrm{a}}$ ditolak, artinya variabel Net Profit Margin tidakberpengaruh dan tidak signifikan terhadap Kebijakan Dividen pada perusahaan sektor Trade, Service, and Investment yang terdaftar di Bursa Efek Indonesia periode 2014-2018.

2. Variabel Firm Size $\left(\mathrm{X}_{2}\right)$ mempunyai nilai $\mathrm{t}_{\text {hitung }}$ 1,916 dengan tingkat signifikan 0,058 . Sedangkan nilai $t_{\text {tabel }}$ adalah sebesar $-1,66023_{\text {dengan }}$ signifikan 0,05 . Sehingga kesimpulannya adalah $-t_{\text {hitung }}<-$ $\mathrm{t}_{\text {tabel }}$ yaitu $-1,916<-1,66023$. Maka keputusannya adalah $\mathrm{H}_{\mathrm{o}}$ ditolak dan $\mathrm{H}_{\mathrm{a}}$ diterima, artinya variabel Firm Size berpengaruh dan tidak signifikan terhadap Kebijakan Dividen pada perusahaan sektor Trade, Service, and Investment yang terdaftar di Bursa Efek Indonesia periode 20142018.

3. Variabel Debt To Equity Ratio $\left(\mathrm{X}_{3}\right)$ mempunyai nilai thitung $-0,679$ dengan tingkat signifikan 0,499. Sedangkan nilai $t_{\text {tabel }}$ adalah sebesar $-1,66023$ dengan signifikan 0,05. Sehingga kesimpulannya adalah $-t_{\text {hitung }}>-t_{\text {tabel }}$ yaitu $-1,916>-1,66023$. Maka keputusannya adalah $\mathrm{H}_{\mathrm{o}}$ diterima dan $\mathrm{H}_{\mathrm{a}}$ ditolak, artinya variabel Debt To Equity Ratio tidakberpengaruh dan tidak signifikan terhadap Kebijakan Dividen pada perusahaan sektor Trade, Service, and Investment yang terdaftar di Bursa Efek Indonesia periode 2014-2018.

4. Variabel Cash Ratio $\left(\mathrm{X}_{4}\right)$ mempunyai nilai $t_{\text {hitung }}$ 1,545 dengan tingkat signifikan 0,126. Sedangkan nilai $t_{\text {tabel }}$ adalah sebesar $1,66023_{\text {dengan }}$ signifikan 0,05 . Sehingga kesimpulannya adalah $t_{\text {hitung }}<t_{\text {tabel }}$ yaitu 1,545> 1,66023. Maka keputusannya adalah $\mathrm{H}_{\mathrm{o}}$ diterima dan $\mathrm{H}_{\mathrm{a}}$ ditolak, artinya variabel Cash Ratio tidakberpengaruh dan tidak signifikan terhadap Kebijakan Dividen pada perusahaan sektor Trade, Service, and Investment yang terdaftar di Bursa Efek Indonesia periode 20142018.

\section{KESIMPULAN}

Berdasarkan hasil penelitian dan pembahasan tentang pengaruh Profitabilitas (Net Profit Margin), Ukuran Perusahaan (Firm Size), Leverage (Debt to Equity Ratio), dan Likuiditas (Cash Ratio) terhadap Nilai Perusahaan (PBV) dapat ditarik kesimpulan bahwa:

1. Profitabilitas (Net Profit Margin) secara parsial tidakberpengaruh dan tidak signifikan terhadap Kebijakan Dividen pada perusahaan Sektor Trade, Service, and Investment yang terdaftar di
Bursa Efek Indonesia periode 2014-2018, dengan nilai $t_{\text {hitung }}<\mathrm{t}_{\text {tabel }}$ yaitu $0,571>1,66023$.

2. Ukuran Perusahaan (Firm Size) secara parsial berpengaruh dan tidak signifikan terhadap Kebijakan Dividen pada perusahaan Sektor Trade, Service, and Investment yang terdaftar di Bursa Efek Indonesia periode 2014-2018, dengan nilai $-\mathrm{t}_{\text {hitung }}<-\mathrm{t}_{\text {tabel }}$ yaitu $-1,916<-1,66023$.

3. Leverage (Debt To Equity Ratio) secara parsial tidakberpengaruh dan tidak signifikan terhadap Kebijakan Dividen pada perusahaan Sektor Trade, Service, and Investment yang terdaftar di Bursa Efek Indonesia periode 2014-2018, dengan nilai $-\mathrm{t}_{\text {hitung }}>-\mathrm{t}_{\text {tabel }}$ yaitu $-1,916>-1,66023$.

4. Likuiditas (Cash Ratio) secara parsial tidakberpengaruh dan tidak signifikan terhadap Kebijakan Dividen pada perusahaan Sektor Trade, Service, and Investment yang terdaftar di Bursa Efek Indonesia periode 2014-2018, dengan nilai adalah thitung < ttabel yaitu 1,545> 1,66023.

5. Hasil nilai $F_{\text {hitung }}$ sebesar 2,899 dengan nilai signifikan 0,026 sedangkan $F_{\text {tabel }}$ sebesar 2,46 dengan signifikan 0,05 . Dengan demikian, dapat dilihat bahwa $F_{\text {hitung }} \geq F_{\text {tabel }}$ atau signifikan 2,899 $\geq 2,46$ dan $0,026 \leq 0,05$ sehingga $\mathrm{H}_{\mathrm{a}}$ diterima dimana Profitabilitas (Net Profit Margin), Ukuran Perusahaan (Firm Size), Leverage (Debt to Equity Ratio), Dan Likuiditas (Cash Ratio) secara simultan berpengaruh dan signifikan terhadap Kebijakan Dividen pada perusahaan Sektor Trade, Service, and Investment yang terdaftar di Bursa Efek Indonesia periode 2014-2018.

\section{DAFTAR PUSTAKA}

Agustina, L., \& Andayani. (t.thn.). PENGARUH KINERJA KEUANGAN, UKURAN PERUSAHAAN, DAN PERTUMBUHAN PERUSAHAAN TERHADAP KEBIJAKAN DIVIDEN. Jurnal Ilmu dan Riset Akuntansi : Volume 5, Nomor 10, Oktober 2016 ISSN : 2460-0585, 21.

Gumanti, T. A. (2013). Kebijakan Dividen. Yogyakarta: UPP STIM YKPN.

Hery. (2015). Analisis Laporan Keuangan (Pendekatan Rasio Keuangan). Jakarta: Caps Publishing.

Mulyawan, S. (2015). Manajemen Keuangan. Bandung: Pustaka Setia. 
Riyanto, B. (2010). Dasar-Dasar Pembelanjaan Perusahaan. Yogyakarta: BPFE.

Rodoni, A., \& Ali, H. (2014). Manajemen Keuangan Modern. Jakarta: Mitra Wacana Media.

sutrisno. (2013). manajenen keuangan ( teori konsep dan aplikasi. yogyakarta: Ekonisis. 